Review Article

\title{
Amperometric Biosensors as an Analytical Tool in Food, Dairy and Fermentation Industries
}

\author{
Shilpa Sivashankar*, Navaneeth S Kumar, Kiran R, Nilakshi Mazumder \\ Department of Biotechnology, Acharya Institute of Technology, Affiliated to Visvesvaraya Technological University (VTU), \\ Soladevanahalli, Bengaluru, Karnataka-560107, India. \\ *Corresponding author's E-mail: ssshilpashiva9@gmail.com
}

Received: 10-08-2020; Revised: 18-10-2020; Accepted: 26-10-2020; Published on: 15-11-2020.

\section{ABSTRACT}

Biosensors are analytical devices that sense the presence of a biological component in the vicinity and generate signals that can be easily detected using a physicochemical detector. With the advent of biosensors, conventional methodologies such as the detection of contaminants in pharmaceutical industries and the diagnosis of diseases via biomarkers have been accelerated to a great extent. The review highlights the use of Amperometric biosensors in three important industries namely, the food, fermentation, and dairy industries, and highlights the potential use of these biosensors in various domains of these industries. These industries can employ the use of amperometric biosensors to control and monitor the presence of various metabolites and constituents that may either be of economic importance or toxic to the consumers. The continuous monitoring of these metabolites is of prime importance as they ultimately determine the quality of the end product. The review also gives a comprehensive description of the modifications done in the amperometric biosensors, using specific biomolecules and chemicals, along with their associated analytical features.

Keywords: Amperometric biosensors, analytical features, industrial applications.

QUICK RESPONSE CODE $\rightarrow$

DOI:

10.47583/ijpsrr.2020.v65i01.010

DOI link: http://dx.doi.org/10.47583/ijpsrr.2020.v65i01.010

\section{INTRODUCTION}

B iochemical analytical techniques have major importance in the field of medicine, pharmaceutics, and other industries and with the origin of biosensors, the continuous monitoring of the processes has become easier. An analytical device that is used to convert a sensitive biological response into an electrical signal using a physicochemical detector is called a biosensor. ${ }^{1}$ The first biosensor as defined in 1962 by Clark and Lyons. ${ }^{2,3}$ Based on forms of signal transduction, biosensors may be categorized as electrochemical, optical, piezoelectric, and thermal sensors. ${ }^{4-8}$ based on the type of electrical property measured, electrochemical biosensors are categorized as potentiometric, amperometric, and conductometric sensors. ${ }^{9-11}$ The utility of biosensor areas are clinical, quality control, diagnostics, medical applications, process control, bioreactors, agriculture and veterinary medicine, bacterial and viral diagnostics, drug production, wastewater treatment from industries, mining, military defense industry etc. ${ }^{12-26}$ Amperometric biosensors are integrated devices that are established based on the estimation of the current generated due to the oxidation or reduction of an electroactive organic component, yielding a distinct quantitative analytical data. ${ }^{27}$ Amperometric biosensors measure the current stream between the anode and cathode when a redox response takes place and the resulting current is found to be proportional to the electroactive element in the solution..$^{28}$ Glucose biosensors are one of the most actively used and researched amperometric biosensors. ${ }^{29}$

Food production and processing industry and its subsequent industry supply food to the population and play a vital role in the economy of a country. The food examination prospects mainly focus on the quality, safety, and authenticity of the process and the resulting products. Amperometric biosensors have great potential in fermentation industries as analytes like phenols, alcohol, and oligonucleotides need to be continuously monitored at different phases of the process. ${ }^{30}$ In the food and dairy industry, there is a need for the detection of impurities like allergens, antibiotic residues, pathogenic microbes, and toxins ${ }^{31-34}$ and amperometric biosensors are found to be of great importance in this domain. Amperometric Biosensors have high sensitivity compared to the traditional methods, which were earlier used to detect the contaminants. Nutritional content and authenticity analysis can also be measured by amperometric biosensors. ${ }^{35,36}$ Biosensors always undergo constant innovations and shortly, they are expected to be linked with the information technology to assist the users in their decision-making progress. ${ }^{37,38}$

In the Fermentation industry, tracking of lactate, ethanol, glucose, fructose, lactic acid, and glycerol is essential for the quality of end product and health concerns. Spectrophotometric methods are currently being employed for the analysis. Several oxidases that are immobilized on the electrodes undergo oxidation to produce hydrogen peroxide. Upon oxidation, the current is 
produced, which is proportional to the concentration of the analyte. The analyte concentration can hence be detected using the amperometric biosensor.

The dairy industry is an industry whose pathogen, adulteration, and toxins, pose a grave risk to the consumer. Detection of pathogen and colostrum adulteration hence is of prime importance and this is done by immobilizing antibodies to the electrodes of the biosensor. The screening of the analyte then takes place amperometrically.

The food industry has a lot of demand for biosensors right from production to packaging. Biosensors are already in use for packaging ${ }^{39}$, but biosensors for industrial processing are yet to be updated. Threats like pathogens, toxins, antibody residues are a risk for human life, and the traditional methods are, however, to be replaced by biosensors, as they are not highly efficient methods for detecting the potential hazards. An amperometric biosensor which is an integration of the sample holder and quantification chamber is designed for industrial employment and is illustrated in Figure 1.

This review aims to provide information about the amperometric biosensors developed for industrial applications in recent years. The biosensors mentioned are tested in lab conditions and are modified to work in mass production and processing. Amperometric detection of analytes in different industries is a vast opportunity for economic benefits, and improving food safety, and scientists across the world have been trying new modifications to improve its analytical parameters and increase its efficiency. Many new and modified additional components, like nanomaterials, nanotubes, platinum, hexadecane, gold electrodes, matrices like sodium alginate, resydrol polymer for immobilization of bioreceptors, etc. have been used to upgrade the properties of biosensors like better conductivity and sensitivity. The review highlights the use of various elements incorporated onto the amperometric biosensors for potential applications in the food, fermentation, and dairy industry.

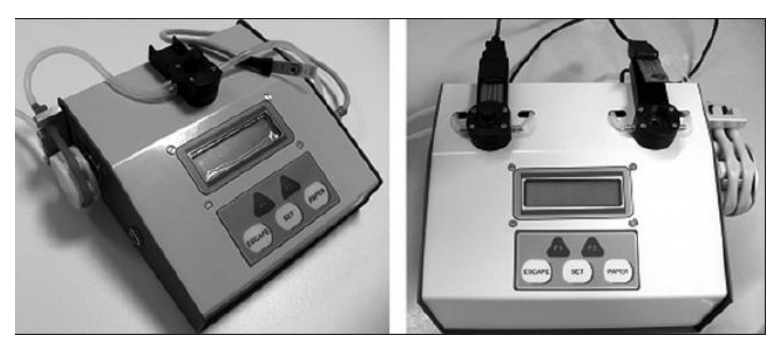

\section{AMPEROMETRIC BIOSENSORS EMPLOYED IN THE FERMENTATION INDUSTRY:}

Sugars present in the raw materials are converted into ethanol and $\mathrm{CO}_{2}$. This process is called fermentation. Fermentation is controlled to decide the quality of the output. ${ }^{40}$ The industry which involves fermentation is a major part of the food processing industry, but the demand for a biosensor in this particular sub-industry is high. The parameters like levels of starch, glucose, lactate, and ethanol need constant monitoring in this industry for obtaining exceptional quality end products and for other economic reasons. ${ }^{41}$ Figure $\mathbf{2}$ illustrates a glucose biosensor, which monitors the fermentation process of hardwood hydrolysate by glucose monitoring using glucose oxidase as the recognition element. The microbial load present in the primal matter and the range of raw products also decide the grade of the final product. ${ }^{42}$ Certain substrates that are specific to the analytes like, oxidases are immobilized on the electrode surface, which binds and reacts with the analytes and produces $\mathrm{H}_{2} \mathrm{O}_{2}$, whose oxidation produces current, measured by the amperometric transducer. The reaction is as follows:

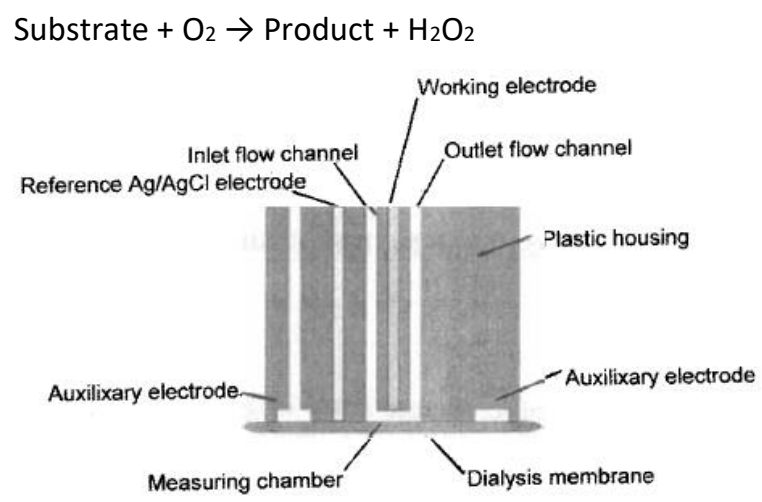

Figure 2: Diagrammatic representation of a glucose biosensor, which monitors the fermentation process of hardwood hydrolysate. ${ }^{28}$

\section{(i) Detection of ethanol concentration in alcoholic beverages:}

Ethanol determination is significant because the level of its concentration determines its economic importance and also determines the nature of the final product. A lot of amperometric biosensors are developed and used recently for ethanol determination. There have been very recent modifications in the sensors for an increase in selectivity and other characteristics like sensitivity, measurement range, accuracy, repeatability, and response time. ${ }^{43}$

(a) $A D H$ based biosensor for ethanol determination: $M$. Boujtita et al. reported an $\mathrm{ADH}$ based ethanol biosensor which focuses on the oxidation of ethanol, resulting in acetaldehyde. NAD+ catalyzes this reaction. $\mathrm{NAD+}$ is converted into $\mathrm{NADH}$ and the oxidation of $\mathrm{NADH}$ takes place, releasing electrons and is monitored by the biosensors amperometrically. ${ }^{44}$ The biosensor uses alcohol dehydrogenase (ADH) and NAD+ modified carbon paste electrodes. The research also shows the response of the sensor studied with different types of pasting liquid, which includes analyzing the concentration of ethanol in wine, beer, and it was compared favorably with spectrophotometry. The hexadecane electrode is used because it showed more sensitivity and linearity. The matrix has minimal effect on the amperometric current measured and 
does not interfere in the result of the ethanol analysis given by the carbon paste electrode modified with $A D H / N A D+$. The measurement time is 20 seconds, and the sample needs a preparation i.e. dilution because the enzyme electrode depends on the dilution factor. The $A D H$ based biosensors have limited operational strength and are dependent on the coenzyme NAD+, which needs persistent recovery in the analysis, which increases the general expense of the production of biosensors. ${ }^{43}$

(b) Amperometric Biosensor for the detection of ethanol, based on ethanol oxidase (AOX) based Polyvinyl chloride ( $P V C$ ) cell: This is an amperometric bioenzymatic biosensor reported by Vinita Hooda.et.al. These biosensors are based on alcohol oxidase integrated with the PVC reaction cell. For the rapid quantification of alcohol, nanomaterials modified working electrodes are used. Alcohol oxidase based alcohol biosensors works by utilizing just molecular oxygen to oxidize ethanol into the corresponding aldehyde with the arrival of $\mathrm{H}_{2} \mathrm{O}_{2}$, without the addition of any other cofactor. The use of multiwalled carbon nanotubes (MWCNTs) and silver nanoparticles (AgNPs) facilitates the direct transfer of electrons between the Horseradish Peroxidase (HRP) enzyme and the electrode. The immobilized AOX onto the outside of the PVC container holds great electrocatalytic movement at physiological $\mathrm{pH}$, and detection takes place amperometrically. Electrochemical cells are constructed using PVC because of its properties like reusability, improved analytical performance, and stability. The currently used alcohol biosensor was compared with this biosensor by conducting experiments with wine samples, and the analytical parameters were improved. Response time is 8 seconds at pH 7.5 at $35^{\circ} \mathrm{C}$ incubation temperature. The result was compared with that of standard analytical methods. $^{45}$

(c) Microbial amperometric biosensor: Many microbial amperometric biosensors are reported for ethanol determination, based on microorganisms like T. brassicas, S. cerevisiae, Acetobacter acetic, or Acetobacter xylinum . ${ }^{46,47}$ L. Rotariu et.al. reported a microbial amperometric biosensor based on yeast cells (Saccharomyces ellipsoids) immobilized on Clark based oxygen electrodes. This biosensor determines the ethanol by the products released by the respiratory activity of the microorganism. The reaction time is 2 minutes. This biosensor utilizes a second Teflon membrane, which shields the biocatalytic yeast layer, which helps for selective determination of ethanol in the presence of glucose. Incubation with ethanol was reported to improve the selectivity of the biosensor. The selective biosensor was used to determine ethanol concentration in alcoholic beverages. The results were compared with the spectrometric method with alcohol dehydrogenase and a good correlation was observed. ${ }^{48}$

$$
\mathrm{RCH}_{2} \mathrm{OH}+\mathrm{O}_{2} \rightarrow \mathrm{RCHO}+\mathrm{H}_{2} \mathrm{O}_{2} 46
$$

\section{Detection of lactate concentration in wine}

Secondary fermentation is called malolactic fermentation, and it is performed by LAB (lactic acid bacteria). Lactate is formed after a series of biochemical reactions performed by LAB. This process can influence the taste and other qualities and attributes of the beverage and hence, it is essential to control its levels. Various innovations in lactate biosensors are reported from all over the world. New trends in biosensors stated below are all tested with the results of the traditional methods and functional correlations have been found. The current measured by the amperometric biosensor is proportional to the concentration of lactic acid. Amperometric biosensors are divided into two types: lactase oxidase-based biosensor (LOx) and lactate dehydrogenase (LDH)-based biosensor. ${ }^{49}$

(a) Bienzymatic biosensor for I-lactate concentration determination: Sandra Perez et al. reported an Amperometric enzymatic biosensor that uses a fusion of Horseradish Peroxidase (HRP) and Lactate Oxidase (LOX) enzymes into a carbon nanotube/polysulfone film by the phase inversion technique and screen-printed electrodes (SPEs) are obtained. Horseradish Peroxidase is a biochemical used as an enzyme in this research. ${ }^{50}$ Ferrocene was applied to the layer as they reportedly improve sensibility, working potential, and permit a decrease of $\mathrm{H}_{2} \mathrm{O}_{2}$ at $100 \mathrm{mV}$. The report has mentioned the estimations done in phosphate buffer solution at $\mathrm{pH}$ 7.5 under batch conditions. The reaction time of the biosensor was 20 seconds. Detection has been conducted on various wine and beer samples. They have compared the outcomes acquired with the biosensor and the results from the spectrophotometric measurements and obtained functional correlations. This device was found to have high accuracy, high sensitivity, low limit of detection, and a quick throughput. However, it is also reported that the shelf-life stability isn't very high and needs improvement in future trials. ${ }^{51}$

(b) Lactate oxidase-based amperometric biosensor using platinum electrode: This amperometric biosensor is intended for the determination of lactate. The report analyzes two techniques involving SensLab platinum printing anodes by immobilizing lactate oxidase on its surface with different types of absorption. The sensor with lactate oxidase immobilized by physical adsorption in Resydrol polymer appears to have both a smaller dynamic range (0.004-0.5 mm lactate) and more sensibility (320 $\mathrm{nA} / \mathrm{mM})$. The immobilization strategy has no impact on results, and this report was obtained when these biosensors were tested. The data obtained by analyzing the lactate concentration in wine and the must during fermentation using 
amperometric lactate biosensor and standard chromatography techniques have a reasonable correlation. The report by L.V. Shkotova et.al. also suggest that the biosensor created can be utilized in the food industry for improvement and also helps in the supervising the procedure of wine aging.$^{52}$

(c) Lactate detection with biosensor integrated with nanoparticles: Nanoparticles are best described as a cluster of atoms, and their size ranges from 1-100 $\mathrm{nm}$. Kang, $\mathrm{H}$ et al. have effectively explained the application of nanoparticles in biosensors to increase its working efficiency. ${ }^{53}$ Amperometric biosensors have been modified and tested with palladium and platinum nanoparticles by L. Shkotova et. al. for analysis of the final product for lactate concentration during fermentation. They observed an increase in bio selectivity upon the incorporation of $\mathrm{Pd}$ and $\mathrm{Pt}$ NPs. This modified biosensor finds effective application for maintaining the excellent quality of wine and for selective detection of lactate in raw material during fermentation. Research has shown that the lactate biosensor function of amperometric transducers has improved sensitivity and selectivity with the incorporation of Pt And Pd nanoparticles along with the Nafion protective membrane. ${ }^{54}$

\section{(iii) Detection of multiple enzymes:}

Multiple analytes are to be maintained in the industrial fermentation process, so multiple oxidase-based biosensors are developed to serve this purpose.

(a) Based on platinum (printed) electrodes and immobilized enzymes: Goriushkina T. B et al. reported a biosensor for application in wine analysis that concentrates on the determination of the concentration of ethanol, glucose, and lactate by immobilization of respective oxidases on printed platinum electrodes. The immobilized oxidases react with the analyte and produce $\mathrm{H}_{2} \mathrm{O}_{2}$ upon oxidation. The current produced is measured by the amperometric transducer. The data of linear response to ethanol, glucose, and lactate within the concentration range is mentioned in Table 1. It was seen that the biosensor activity did not alter even after two months of fabrication for ethanol and glucose. However, for lactate biosensor activity, the operational stability lasted for four days. Research also showed high selectivity to the substrate and commercial applicability during the fermentation of wine, must for analysis of ethanol, glucose, and lactate in wine and must during its fermentation. Research has also reported the correlation of results of various types of wine like red, white, and rose wine and also dry, strong, and sweet forms and must with other amperometric biosensors and the traditional methods. ${ }^{55}$

(b) Screen printed biosensors for real-time monitoring of alcoholic fermentation: Screen-printed biosensors for the determination of glucose, ethanol, and fructose are combined with convenient instrumentation for real-time monitoring. S. Piermarini et.al reported the application of these biosensors to screen micro alcoholic fermentation (micro ALFs) processes in red wine. The ethanol and glucose biosensors fabrication was done on graphite screen-printed sensors and further altered with Prussian Blue coupled with oxidase enzyme. The electrochemical mediator permits a delicate and particular location of $\mathrm{H}_{2} \mathrm{O}_{2}$, at applied potential (50 $\mathrm{mV}$ ). For fructose, a normal screen-printed sensor was coated with fructose hydrogenase and an electrochemical mediator phenazine methosulphate was used for acting as an enzymatic co-substrate. They have reported the working range, reproducibility of probe fabrication, and its stability. The research shows that they have collected samples of fortified must-wine, which were tested to monitor the micro-ALFs in the samples induced by two strains of yeast. The data were also compared with spectrophotometry, and a good correlation was reported. The fermentation profiles were analyzed at different time intervals, and the data was able to determine the typical fermentation phases. They also indicated the differences in the metabolic behavior of the two strains. ${ }^{56}$

(c) Detection of enzymes using carbon film resistors: Multiple oxidase-based enzyme electrode biosensors use Carbon film resistors as transducers for their development. The resistor electrodes were altered with Prussian Blue (PB), and then a layer of enzymes was immobilized covalently. The substrates of the enzymes are detected by the reduction reaction of hydrogen peroxide against $\mathrm{Ag} / \mathrm{AgCl}$ in response time of 1-2 minutes. Finally, the electrochemical biosensors were used to analyze complex food matrices-yogurt, wine, and must. The above experiment was compared with the spectrophotometric reference method, which indicated a good correlation with the results and indicated that it is suitable for wine and food analysis. These biosensors have some unique properties which make this an excellent material for disposable or easily renewable sensors. Voltammetric techniques and EIS have been used to test its stability towards carbon resistor substrates. This research mainly focuses on wine process control as the electrodes are studied and analyzed in wine samples. The detection limits of these biosensors are comparable with screen-printed biosensors and platinum-based biosensors in terms of sensitivity. They are low cost and are being tested for other analytes. They are hence, found to be suitable for food screening. The different designs allow swift immobilization of biological substrates and compounds. The research has also shown that the 
enzyme biosensors with carbon film resistors are suitable for complex matrices..$^{57}$
The various important analytical characteristics of the biosensors used in the fermentation industry are mentioned in Table 1.

Table 1: The analytical characteristics of amperometric biosensors used in the fermentation industry.

\begin{tabular}{|c|c|c|c|c|c|}
\hline $\begin{array}{l}\text { The electrode used in the } \\
\text { Biosensor }\end{array}$ & Analyte & $\begin{array}{l}\text { Limit of } \\
\text { detection }\end{array}$ & Linear detection range & Potential & Sensitivity(A/mM) \\
\hline $\begin{array}{l}\text { Alcohol dehydrogenase } \\
\text { (ADH) on NAD+ modified } \\
\text { carbon paste electrode. }{ }^{43}\end{array}$ & Ethanol & - & $0 \mathrm{M}$ to $11 \mathrm{mM}$ & $0.7 \mathrm{~V}$ & - \\
\hline $\begin{array}{l}\text { Alcohol oxidase coupled } \\
\text { PVC reaction cell on } \\
\text { nanomaterial modified } \\
\text { electrodes. }{ }^{45}\end{array}$ & Ethanol & $0.0001 \mu \mathrm{M}$ & $0.01 \mathrm{mM}$ to $50 \mathrm{mM}$ & $\begin{array}{l}-0.75 \mathrm{~V} \text { to } \\
1.2 \mathrm{~V}\end{array}$ & $155 \mu \mathrm{Am} / \mathrm{Mcm}^{2}$ \\
\hline $\begin{array}{l}\text { Yeast cell immobilized on } \\
\text { Clark type oxygen } \\
\text { electrode. }{ }^{48}\end{array}$ & Ethanol & $1.5 \mathrm{mM}$ & $3 \mathrm{mM}$ to $50 \mathrm{mM}$ & $-650 m V$ & - \\
\hline $\begin{array}{l}\text { LOx and HRP in Carbon } \\
\text { nanotube on SRP. }{ }^{51}\end{array}$ & L-lactate & $5.6 \times 10^{-7} \mathrm{M}$ & $\begin{array}{c}1.1 \times 10^{-6} \mathrm{M} \text { to } 5.6 \\
\times 10^{-4} \mathrm{M}\end{array}$ & $-100 m V$ & $1168.8 \mu \mathrm{A} / \mathrm{mM}$ \\
\hline $\begin{array}{l}\text { LOx in resydrol polymer on } \\
\text { platinum printed } \\
\text { electrode. }{ }^{52}\end{array}$ & Lactate & - & $0.004 \mathrm{mM}$ to $0.5 \mathrm{mM}$ & $\begin{array}{l}\text { OV to } \\
3000 \mathrm{mV}\end{array}$ & $320 \mathrm{nA} / \mathrm{mM}$ \\
\hline $\begin{array}{l}\text { Platinum and palladium } \\
\text { nanoparticles. }{ }^{54}\end{array}$ & Lactate & $0.1 \mu \mathrm{M}$ & $0.05 \mathrm{mM}$ to $0.8 \mathrm{mM}$ & OV to $1.0 \mathrm{~V}$ & $3.03 \mathrm{nAm} / \mathrm{Mcm}^{2}$ \\
\hline $\begin{array}{l}\text { Oxidases immobilized on } \\
\text { electrodes. }{ }^{55}\end{array}$ & $\begin{array}{ll}\text { - } & \text { Ethanol } \\
\text { - } & \text { Glucose } \\
\text { - } & \text { Lactate }\end{array}$ & $\begin{array}{ll}\text { - } & 0.03 \mathrm{mM} \\
\text { - } & 0.04 \mathrm{mM} \\
\text { - } & 0.008 \mathrm{mM}\end{array}$ & $\begin{array}{ll}\text { - } & 0.3 \mathrm{mM} \text { to } 40 \mathrm{mM} \\
\text { - } & 0.04 \mathrm{mM} \text { to } 2.5 \mathrm{mM} \\
\text { - } & 0.008 \mathrm{mM} \text { to } 1 \mathrm{mM}\end{array}$ & $\begin{array}{c}0 \text { to } \\
600 \mathrm{mV}\end{array}$ & - \\
\hline $\begin{array}{l}\text { Graphite screen-printed } \\
\text { sensors modified with } \\
\text { Prussian Blue coupled with } \\
\text { oxidase enzyme. }{ }^{56}\end{array}$ & $\begin{array}{l}\text { - Glucose } \\
\text { - L-Glutamat } \\
\text { - L-Lactate } \\
\text { - Ethanol }\end{array}$ & $1 \mu \mathrm{M}$ & $\begin{array}{ll}\text { - } & 10 \mu \mathrm{M}-800 \mu \mathrm{M} \\
\text { - } & 10 \mu \mathrm{M}-700 \mu \mathrm{M} \\
\text { - } & 10 \mu \mathrm{M}-500 \mu \mathrm{M} \\
\text { - } & 10 \mu \mathrm{M}-700 \mu \mathrm{M}\end{array}$ & - & $\begin{array}{l}\text { - } 8 \mu \mathrm{A} / \mathrm{mM} \\
\text { - } 7 \mu \mathrm{A} / \mathrm{mM} \\
\text { - } 10.4 \mu \mathrm{A} / \mathrm{mM} \\
\text { - } 5.5 \mu \mathrm{A} / \mathrm{mM}\end{array}$ \\
\hline $\begin{array}{l}\text { Screen-printed sensors } \\
\text { modified with Prussian Blue } \\
\text { coupled with oxidase } \\
\text { enzyme with carbon film } \\
\text { resistors as transducers } .^{57}\end{array}$ & $\begin{array}{l}\text { - Glucose } \\
\text { - Fructose } \\
\text { - Ethanol }\end{array}$ & & 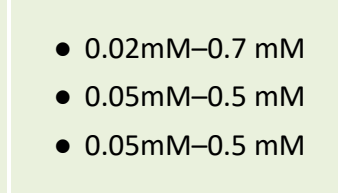 & $70 \mathrm{mV}$ & - \\
\hline
\end{tabular}

'-' Refers as not mentioned

\section{Amperometric Biosensors used in Dairy Industry}

The dairy industry includes the harvesting of milk from cattle and processing of the milk to produce different products like butter, curd, etc. A variety of adulteration and pathogen contamination takes place during the harvesting of milk. Therefore, biosensors have been developed, modified, and experimented for replacing the traditional methods and detecting impurities with higher accuracy. For instance, animal-specific IgG is detected in milk to determine milk adulteration using the antibody immobilized immunosensor, which is depicted in Figure 3. All the analytical properties are stated in Table $\mathbf{3}$. 


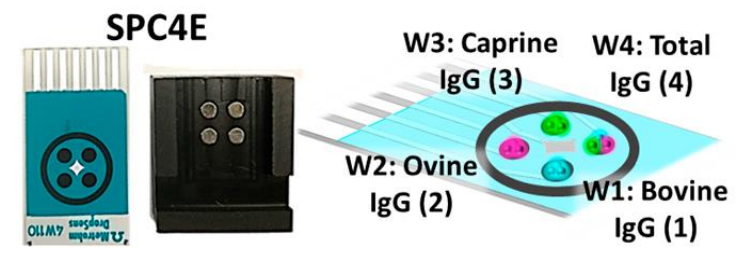

Figure 3: Schematic representation of the immunosensor with the platinum screen printed electrodes to detect animal-specific IgG in milk. ${ }^{76}$

\section{Lactose detection in milk}

Lactose detection in milk is essential because the lactose level is a key marker for the assessment of milk and the discovery of abnormalities. For instance, milk from cows struggling with mastitis has lower lactose levels. ${ }^{58}$ Also, lactose is a fundamental parameter in wastewater management and veterinary medicine. ${ }^{59}$ Gastrointestinal malignancy stipulates a greater amount of lactose in blood.

(a) Lactose detection using a gold electrode: The lactose biosensor was assembled by $\boldsymbol{\beta}$-Gal, GOD, HRP immobilization, and the mediation of Tetrathiafulvalene (TTF) on the gold disk electrode. Glucose is produced when $\boldsymbol{\beta}$-Gal catalyzed lactose hydrolysis takes place. Glucose then oxidizes into gluconic acid and $\mathrm{H}_{2} \mathrm{O}_{2}$. The product is then reduced with the involvement of HRP, mediated by TTF. TTF reduction results in the production of amperometric signals proportional to lactose concentration. It shows good analytical performance, including simple and rapid analytical technologies with amperometric detection. The lifespan of this biosensor is 28 days. The effect of potential interference has been evaluated by F. Conzuelo et. al. The biosensors have been applied for lactose determination in milk and other edible items like chocolate, cheese, butter, yogurt, and mayonnaise. The results were compared with traditional methods and commercial enzyme kits and a good correlation was found. ${ }^{60}$

(b) Lactose determination by biosensor in raw milk: Lourenço et al reported raw milk lactose determination using a biosensor. The reported new amperometric biosensor was established through the concurrent immobilization of enzymes namely galactose oxidase and $\boldsymbol{\beta}$-galactosidase on derivatized polyethersulfone membrane. ${ }^{61}$ The biosensors can be stable for 20 days. The $\boldsymbol{\beta}$-linkages of galactose and glucose develop lactose as it is a disaccharide. $\beta$ galactosidase and galactose oxidase act as a catalyst. The former catalyzes the lactose hydrolysis which results in galactose and glucose and the latter catalyzes the oxidation of galactose into galactonic acid and $\mathrm{H}_{2} \mathrm{O}_{2}$. A constant voltage is supplied to the biosensor and variation of current is calculated and hence the concentration of lactose is determined. ${ }^{62}$

\section{Amperometric lysine biosensor by using two different} electrodes

Lysine is an essential amino acid, which is popularly used as a nutritional supplement in the animal feed industry as well as in human food products. ${ }^{63}$ Diseased conditions like tiredness, bloodshot eyes, inability to concentrate, retarded growth, anemia, hair loss, and reproduction problems show a low level of lysine in the blood and other body fluids. ${ }^{64}$ Due to the clinical, dietary, and pharmaceutical criticalness of this amino acid, quick strategies are required for the location of lysine in different frameworks. ${ }^{65,66}$

Two amperometric L-lysine biosensors were reported by Nidhi Chauhan et al., who distinguished them using instruments like SEM. The electrodes used in biosensors were modified by two different components namely Polyaniline (PANi) and 3,3'-Diaminobenzidine (DAB), in different apparatus, and were stored at $4^{\circ} \mathrm{C}$. Eventually, the modified biosensors have experimented with milk samples. After 100 uses, it was seen that the PANi modified electrode was stable for 120 days and the DAB modified electrode was stable for 90 days. Ideal material for biosensors is already initiated by Gold nanoparticles (AuNPs), especially for those using electrochemical detection, because the gold surface is preferable for the binding of biomolecules and direct electron transfer. ${ }^{67}$ When lysine is oxidized in the presence of LOx, a-keto-3aminocaproate, $\mathrm{H}_{2} \mathrm{O}_{2}$, and $\mathrm{NH}_{3}$ is formed. The oxidation of $\mathrm{H}_{2} \mathrm{O}_{2}$ then results in the electron flow and current generation in LOx/AuNPs/C-MWCNT/PANi/Au electrode. They reported that the electrode modified by PANi gives better systematic properties than the DAB modified electrode; it was utilized for the identification of lysine in real samples like milk, pharmaceutical tablets, and serum proteins. Samples from milk were absorbed for $6 \mathrm{~N} \mathrm{HCl}$ in $15 \mathrm{~min}$, following which the samples were escorted to $\mathrm{pH}$ 7.0 with $1 \mathrm{M} \mathrm{KOH}$, and then the samples were evaluated for lysine content. The use of PANi/DAB and nanoparticles (AuNPs) in the manufacturing of lysine biosensors gave the results in its much-improved system performance than the earlier used biosensors concerning the response of time ( $2 \mathrm{~s}$ and $4 \mathrm{~s}$ ), detection limit ( 5 and $20 \mu \mathrm{M}$ ), higher stability (up to 4 months) and no involvement from different serum substances. They also conducted experiments and found the PANi electrode has better performance than the DAB electrode. ${ }^{63}$

\section{Discrimination of milk with a multisensor system}

Lactose intolerance or weight problems might cause people to utilize lactose-free milk and coffee fats milk for their daily needs. ${ }^{68}$ Electrochemical biosensors display excessive selectivity and may play an essential function in enhancing the effective manipulation of milk on lactose levels. ${ }^{69,70}$

Coral Salvo-Comino et al. developed a layer-by-layer technique for the analysis of milk using a bi-sensor system because of its low cost and intrinsic simplicity. ${ }^{71}$ There are 
two sensing units present in this system. The first sensor consists of anodic and cathodic parts: anodic part is copper sulfonate phthalocyanine (CUPcS), which acts as an electrocatalyst. The cathodic part consists of a mixture of an ionic liquid (IL) (1-butyl-3-methylimidazolium tetrafluoroborate), which expands the active site, along with $\mathrm{CHI}$ (chitosan) which increases the efficiency of the electron transfer and the conductivity. It is represented as $[\mathrm{CHI}+\mathrm{IL} / \mathrm{CuPcS}]_{2}$. The immobilization of galactose oxidase acts as the second sensing unit. The biosensor is denoted as $\left([\mathrm{CHI}+\mathrm{IL} / \mathrm{CuPcS}]_{2}-\mathrm{GAO}\right)$. Sensors were blended to shape into electronic tongues for milk analysis. The enzyme GAO acts as an electron mediator. Principal evaluation of the biosensor is the capacity of the sensor system to distinguish among milk samples with distinctive lactose content, but it was also tested with galactose. The sample milk was collected from local stores with different lactose and fat content, and they successfully experimented and reported the spoilage and lactose content. The biosensor has been tested on milk samples, and the results have been correlated with the traditional methods. They also experimented with the biosensor for the detection of lactose, fat, protein content, and acidity by using PLS-1. ${ }^{72}$

\section{Amperometric immunosensor for the adulterant detection in milk}

Milk, olive oil, honey, orange juice, saffron, coffee, and apple juice are prominently the most frequent targets for adulteration. ${ }^{73}$ Milk is harvested from cattle like bovine, ovine, and caprine, and these kinds of milk are similar, therefore milk adulteration is hard to identify. ${ }^{74,75}$

Víctor Ruiz-Valdepeñas Montiel et al. reported the use of amperometric immunosensor for the detection of adulterants in milk by using colostrum from various animals. The system is set up by sandwiching the speciesspecific IgG and the selective antibody pairs, and this is set up on carboxylic acid-modified magnetic beads connected to four screen-printed carbon working electrodes. When the antibodies are present in the milk sample, the sandwich which is conjugated with HRP selectively captures it. The antibody in the sandwich captures the antibodies present in the milk and through the magnetic beads, amperometric transduction takes place near the $\mathrm{Ag}$ electrode using the $\mathrm{H}_{2} \mathrm{O}_{2}$ system. They conducted experiments on milk samples for the screening of antibodies at the level demanded by European legislation. The time taken for detection was 30 minutes. LOD and time duration was less compared to traditional methods like ELISA. The developed biosensor is easy and simple to use by the training staff, and the process can be performed during milk collection or at the dairies. ${ }^{76}$

\section{Amperometric urea biosensor}

Urea is a compound found in blood and other biological fluids. Consistent scrutiny of urea in milk can be utilized to foresee the state of the cattle's wellbeing and one can predict the protein necessity in its eating regimen. ${ }^{77,78}$ This strategy includes the utilization of electrochemical urea biosensors. Urea biosensor is used for tracking the urea content material of adulterated milk. Immobilization of the urease over altered electrodes decides the sensitivity and reproducibility of the biosensor. Urease immobilized electrodes were fabricated by a polymeric membrane, based on polyaniline, and acts as new electron mediating support material. It was reportedly tested at different thicknesses and applied for the screening of urea by amperometry. Florina Brânzoi et al. have reported high sensitivity and other analytical properties by varying and testing the physical properties of the biosensor electrode. The biosensor has been tested on milk samples with urea contamination and good correlation was found with the results of traditional methods. ${ }^{79}$

\section{Pathogen detection in milk (Listeria monocytogenes detection)}

Listeria monocytogenes (LM) is the most dreadful foodborne microorganism. E. coli 0157:H7, Salmonella spp. and Listeria monocytogenes, are among the most commonly examined food-borne microorganisms. ${ }^{80}$ Despite the fact L. monocytogenes is infective to all human population, it has an affinity to cause particularly serious issues in pregnant ladies, children, older and immunosuppressed people. ${ }^{81}$

Ying Lu et al. have reported an immunosensor created by immobilizing HRP-anti-L. monocytogenes antibodies onto the outside of the multiwalled carbon nanotube fibers with both physical and chemical techniques. The impact of immuno-electrode change techniques on the detection of sensitivity and stability is reported. The experiments conducted with the sample showed high specificity, storage stability, and high reproducibility (RSD<6.5\%). This immunosensor specificity is examined by using a milk sample. The reported biosensor detected L. monocytogenes in mixed bacteria of milk sample and showed good specificity, which demonstrated the utilization of immunosensor for the rapid detection of $\mathrm{L}$. monocytogenes for applications in the protection of public health. ${ }^{82}$

\section{Detection of Escherichia coli by amperometric biosensor}

E.coli 0157 is a pathogenic strain and can cause diseases that result in stomach cramps and gentle looseness of the bowels and more deadly complications like hemorrhagic colitis (ridiculous diarrhea), haemolytic uremic disorder (HUS, prompts to kidney failure), and thrombotic thrombocytopenic purpura (TTP). ${ }^{83,84}$ Escherichia coli (E.coli) 0157 is one such bacterial species that brought about numerous principal outbreaks in the past.

$\mathrm{N}$. Dhull et al. proposed the development of amperometric biosensors for the detection of E. coli O157. The biosensor was prepared by covalently binding antibodies on a nanostructured Nickel oxide ( $\mathrm{NiO}$ ) thin film using the $\mathrm{Rf}$ magnetron sputtering technique ${ }^{85}$ and further on conducting ITO coated glass substrates (NiO/ITO). NiO helps in quick charge transfer providing support to the antibodies increasing the target capture efficiency and 
hence detection of $\mathrm{E}$. coli. The biosensor was tested in dilute milk samples and results were correlated with traditional methods like PBS buffer ${ }^{86}$ and Plate count method $^{87}$ and the output was in deviation in the range of $10 \%$. Experiments have been conducted and reported showing that the biosensor has high specificity and selectivity towards the target pathogen even in mixed culture. $^{88}$

The important analytical characteristics of the biosensors used in the dairy industry are mentioned in Table 2.

Table 2: Analytical properties of the amperometric biosensors used in the dairy industry

\begin{tabular}{|c|c|c|c|c|c|}
\hline $\begin{array}{l}\text { The electrode used in the } \\
\text { Biosensor }\end{array}$ & Analyte & L.R [M] & Sensitivity[nA/M] & LOD [M] & Potential [V] \\
\hline $\begin{array}{l}\boldsymbol{\beta} \text {-Gal, GOD, HRP and the } \\
\text { mediation of TTF on gold } \\
\text { disk electrode. } 60\end{array}$ & Lactose & $\begin{array}{c}1.5 \times 10^{-6} \mathrm{M} \text { to } 1.2 \times 10^{-4} \\
\mathrm{M}\end{array}$ & $6.04 \times 10^{5}$ & $4.7 \times 10^{-7} \mathrm{M}$ & $+0.00 \mathrm{~V}$ \\
\hline $\begin{array}{l}\boldsymbol{\beta} \text {-galactosidase and } \\
\text { galactose oxidase on } \\
\text { polyethersulfone } \\
\text { membrane. } 62\end{array}$ & Lactose & $\begin{array}{c}0.0043 \mathrm{~mol} \mathrm{dm}^{-3} \\
\text { and } 0.031 \mathrm{~mol} \mathrm{dm}^{-3}\end{array}$ & 6.81 & - & $+700 \mathrm{~V}$ \\
\hline $\begin{array}{c}\text { LOx/AuNPs/c- } \\
\text { MWCNT/PANi/Au } \\
\text { electrode.63 } \\
\text { 'LOx/AuNPs/c- } \\
\text { MWCNT/DAB/Au } \\
\text { electrode.63 }\end{array}$ & $\begin{array}{l}\text { Lysine }[\mathrm{PANi}] \\
\text { Lysine [DAB] }\end{array}$ & $\begin{array}{l}5 \times 10^{-6} \mathrm{M} \text { to } 6 \times 10^{-4} \mathrm{M} \\
25 \times 10^{-6} \mathrm{M} \text { to } 6 \times 10^{-4} \mathrm{M}\end{array}$ & - & $\begin{array}{l}\text { - } 5 \times 10^{-6} \mathrm{M} \\
\text { - } 25 \times 10^{-6} \mathrm{M}\end{array}$ & $0.4 \mathrm{~V}$ \\
\hline $\begin{array}{l}\text { Carboxylic acid-modified } \\
\text { magnetic beads } \\
\text { connected to four screen- } \\
\text { printed carbon } \\
\text { electrodes. } 76\end{array}$ & $\begin{array}{l}\text { Bovine-[IgG] } \\
\text { Ovine-[IgG] } \\
\text { Caprine-[IgG] }\end{array}$ & $\begin{array}{l}2.6-250 \mathrm{ng} \mathrm{m} / \mathrm{L} \\
2.7-250 \mathrm{ng} \mathrm{m} / \mathrm{L} \\
2.2-250 \mathrm{ng} \mathrm{m} / \mathrm{L}\end{array}$ & - & $\begin{array}{l}0.74 \mathrm{ng} \mathrm{m} / \mathrm{L} \\
0.82 \mathrm{ng} \mathrm{m} / \mathrm{L} \\
0.66 \mathrm{ng} \mathrm{m} / \mathrm{L}\end{array}$ & $-0.2 \mathrm{~V}$ \\
\hline $\begin{array}{c}\text { HRP-anti-L. } \\
\text { monocytogenes } \\
\text { antibodies over } \\
\text { multiwalled carbon } \\
\text { nanotube fibers on } \\
\text { immuno-electrode. } 82\end{array}$ & L. monocytogenes & $10^{2}$ to $10^{5} \mathrm{cfu} / \mathrm{mL}$ & - & $1.07 \times 10^{2} \mathrm{CFU} / \mathrm{mL}$ & - \\
\hline $\begin{array}{l}\text { Antibodies on a NiO film } \\
\text { on ITO coated glass } \\
\text { substrates (NiO/ITO). } 88\end{array}$ & E. coli & $\begin{array}{l}10^{1} \text { to } 10^{7} \\
\text { cells } / \mathrm{mL}\end{array}$ & $10^{\circ}$ cell $/ \mathrm{mL}$ & $-0.3 \mathrm{~V}$ to $0.8 \mathrm{~V}$ & - \\
\hline
\end{tabular}

\section{-' Refers as not mentioned}

\section{USE OF AMPEROMETRIC BIOSENSORS IN}

\section{Food Industry}

The food industry involves the use of biosensors at each step of the processing and packaging stages as these biosensors effectively detect the toxins, pathogens, allergens, and other contaminants along with their concentration. Figure 4 depicts an immunosensor that detects a common allergen, Ara $\mathrm{h} 1$ (peanut allergen).

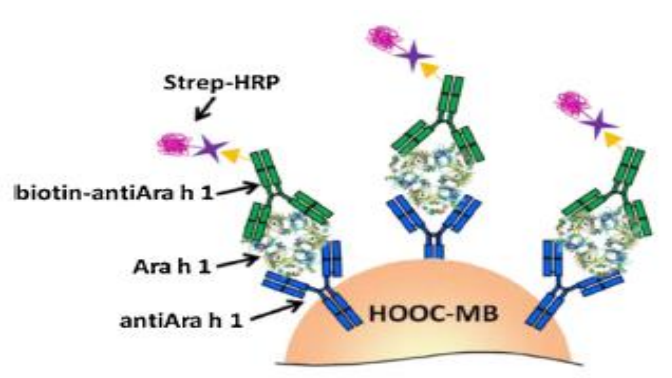

Figure 4: Schematic representation of the Ara h1 immunosensor constructed with antiAra h1 antibodies and $\mathrm{COOH}$ modified magnetic beads. ${ }^{127}$ 


\section{Detection of tyramine (1-hydroxy-4-ethyl aminobenzene)}

Tyramine is a type of biogenic amine. There are many commercial or home purified based enzymes for which biosensors have been made to determine tyramine content. ${ }^{89,90}$ The biogenic amines are considered as quality markers of nourishment in human beings based on the levels of their presence in our diet. ${ }^{91-95}$

Irina Mirela Apetreia et al. have reported a stable amperometric biosensor for tyramine detection in an aqueous medium with the electrode immobilized by tyrosinase using the cross-linking method. This immobilization takes place over phosphate-doped polypyrrole film. The biosensor was applied in sauerkraut samples. The polypyrrole slim film protects its biocatalytic movement well. This enzyme is immobilized for selective detection, whose action is towards the phenolic group of tyramine. They have also reported the characteristics of this biosensor like linear range, detection limit, which has been mentioned in Table 3. High repeatability and longterm stability and other characteristics are reported after conducting experiments in this biosensor. They also have demonstrated the suitability of amperometric detection of tyramine in the salted sauerkraut samples. ${ }^{96}$

\section{Detection of Salmonella pullorum contamination}

Salmonella, which is the most often announced reason for the food-borne sickness in the world, is broadly dispersed into creatures and conditions..$^{97-99}$ The traditional methods to detect Salmonella contamination like plate count techniques require 3-4 days for hypothetical outcomes and 5-7 days for affirmation. ${ }^{100}$

Guoyan Liu et al. demonstrated an amperometric biosensor that utilizes screen printed electrodes immobilized by anti-Salmonella polyclonal antibodies on the cellulose nitrate layer. This amperometric biosensor has improved selectivity and sensitivity for the Salmonella pullorum. The disproportion of hydrogen peroxide is catalyzed by bacterial catalase and the product obtained, when added on the reaction area of the SPEs, helps in easy and rapid detection of S. pullorum. Bacterial catalase (a biomarker for the bacterium) is responsible for the rapid detection of the microbe and the detection time was found to be 10 minutes. The chicken samples were obtained from different markets and were experimented with the biosensor and improved analytical characteristics were reported. This biosensor has rapid detection properties and is cost-effective. ${ }^{101}$

\section{Determination of the egg white allergen, ovomucoid} (OM) at trace levels in fresh and baked food

Eggs, along with milk, are recognized as allergenic components in European youngsters. Egg hypersensitivity principally influences children under three, but the majority of them grow out of their hypersensitivity by the early school years. ${ }^{102}$ This strong allergenicity is accepted to rely upon the security of OM against denaturation, accumulation, and proteolytic debasement. ${ }^{103-109}$
Ovomucoid, an egg white allergen, is determined by the biosensor reported by S. Bened et al. It is commonly detected by commercial ELISA kits. This biosensor has been tested and employed on low-level egg residues like unprocessed food samples of eggs, wheat flour, and baked food samples like bread. In this biosensor, immunocomplex is formed by antibody, target protein allergen, and the HRP labeled detector; this is captured by carboxylic acid-functionalized magnetic beads, which results in the formation of a magnetic bioconjugate. This bioconjugate is then immobilized on the surface of a screen-printed carbon electrode (SPCE), and amperometric detection is carried out. They determined the Ovomucoid using the Hydroquinone as an electron transfer mediator and $\mathrm{H}_{2} \mathrm{O}_{2}$ substrate. Convenient routine screening analysis is possible with the high sensitivity of the sensor for consumer protection. The linearity and other analytical properties of the biosensor have been stated in Table $3 .{ }^{110}$

\section{Detection of Aflatoxin B1}

Aflatoxin B1 (AFB1), a mycotoxin, is the most common and harmful contaminant in human food and animal feed, and hence, its detection in food items is important. ${ }^{111}$ Sodium alginate-altered anodes can give a great microenvironment to catalysts, improving their strength, keeping up their bioactivity, and drawing out the capacity of the biofilm. ${ }^{112-117}$

Amani Chrouda et al. reported a biosensor for the determination of aflatoxin B1 via inhibition of acetylcholinesterase (AChE). As a sensing bio element, AChE was immobilized in the sodium alginate (herbal biopolymer) matrix-Au electrode. The low detection limit is a promising function of this biosensor in comparison to spectrophotometric techniques for AFB1 detection. The AChE activity inhibition is proportional to the AFB1 concentration. By experiments, it was reported that the sodium alginate composite exhibited a development within the overall performance of the biosensor (storage stability, and reproducibility) and offers a biocompatible host matrix that retains enzyme molecules with the aid of using chemical cross-linking. ${ }^{118}$

\section{Detection of Vibrio parahaemolyticus}

V. parahaemolyticus is a Gram-negative halophilic microorganism and a significant food-borne microbe that causes diarrheal illness particularly in people consuming seafood. ${ }^{119-121}$ The hetero-sandwich electrochemical biosensor $^{122}$ gives an ultrasensitive apparatus for the quantification of an assortment of microbe if fitting antibodies and aptamers are accessible.

V. parahaemolyticus detecting antibody-aptamer-based hetero-sandwich amperometric biosensor is reported by Jun Teng et al. The gold electrode surface contains an antibody that seizes the pathogen. An aptamer containing an ssDNA probe is incubated with the immunocomplex formed. Rolling circle amplification is a process where a circular DNA template is used to amplify a short DNA 
strand with the help of various DNA or RNA polymers. ${ }^{123}$ The hetero-sandwich then formed by an antibody-aptamer allows signal intensification by rolling circle amplification. Methylene blue is added as an electrochemical DNA probe. The amperometric signal is obtained, and the pathogen is detected. This biosensor has experimented in spiked fish samples and high sensitivity was found compared to other sensing techniques. ${ }^{124}$

\section{Detection of Peanut Allergen Ara h1}

Since no treatment has been observed for peanut allergy, the peanut is one of the maximum allergic ingredients in the world. $^{125}$ V. Ruiz-Valdepenas Montiel et al. have reported an electrochemical immunosensor for the Ara h1 detection in human saliva samples. Eight A. hypogaea proteins (Ara $\mathrm{h} \mathrm{1-8)}$ ) are now considered to be the most significant peanut allergens. ${ }^{126}$
A disposable amperometric immunosensor primarily based on the usage of magnetic beads (MBs) had been demonstrated for the detection of Ara h1 detection (the fundamental peanut allergen) in 2 hours. The traditional technique involves protein-based assay and PCR. The immunosensor makes use of a sandwich configuration between biotinylated detection antibodies and carboxylic acid-altered MBs (HOOC-MBs). Low detection limit, high selectivity, a terrific reproducibility (RSD $=6.3 \%$ ) for six various immunosensors, and a beneficial life of 25 days had been reported. V. Ruiz-Valdepenas Montiel et al. reported excellent analytical performance, flexibility, and ease of the MBs and mass-produced electrochemical transducers help in the selective and sensitive detection of food allergens. $^{127}$

The important analytical characteristics of the biosensors used in the food industry are mentioned in Table 3.

Table 3: Analytical characteristics of biosensors used in the food industry

\begin{tabular}{|c|c|c|c|c|c|}
\hline Electrode used in the Biosensor & Analyte & Limit of detection & $\begin{array}{l}\text { Linear detection } \\
\text { range }\end{array}$ & Potential & Sensitivity \\
\hline $\begin{array}{l}\text { Tyrosinase immobilized phosphate-doped } \\
\text { polypyrrole film on an electrode. }{ }^{96}\end{array}$ & Tyramine & $\begin{array}{l}4 \times 10^{-6} \mathrm{M} \text { to } \\
80 \times 10^{-6} \mathrm{M}\end{array}$ & $5.7 \times 10^{-7} \mathrm{M}$ & $-0.250 \mathrm{~V}$ & $0.1069 \mathrm{~A} / \mathrm{M}$ \\
\hline $\begin{array}{l}\text { Anti-salmonella polyclonal antibodies } \\
\text { immobilized over cellulose nitrate layer on } \\
\text { Screen-printed electrode. }{ }^{101}\end{array}$ & $\begin{array}{l}\text { Salmonella } \\
\text { pullorum }\end{array}$ & $\begin{array}{c}1.75 \times 10^{\circ} 2 \\
\text { CFU ml-1 to } 23.63\end{array}$ & $100 \mathrm{CFU} \mathrm{m}{ }^{-1}$ & $0.55 \mathrm{~V}$ & - \\
\hline $\begin{array}{l}\text { Antibody-allergen protein-HRP and } \\
\text { magnetic beads on screen printed } \\
\text { electrodes. }{ }^{110}\end{array}$ & Ovomucoid & 0.3 to $25 \mathrm{ng} \mathrm{ml}^{-1}$ & $0.1 \mathrm{ng} \mathrm{ml}^{-1}$ & $-0.20 \mathrm{~V}$ & - \\
\hline $\begin{array}{l}\text { AChE immobilized on sodium alginate on a } \\
\text { gold electrode }{ }^{118}\end{array}$ & Aflatoxin B1 & 0.1 to $100 \mathrm{ng} / \mathrm{mL}$ & $0.1 \mathrm{ng} / \mathrm{mL}$ & $\begin{array}{c}-0.4 \mathrm{~V} \text { to } \\
0.6 \mathrm{~V}\end{array}$ & - \\
\hline $\begin{array}{l}\text { Antibody-aptamer sandwich on a gold } \\
\text { electrode. }{ }^{124}\end{array}$ & $\begin{array}{l}\text { Vibrio } \\
\text { parahaemoly } \\
\text { ticus }\end{array}$ & $\begin{array}{l}2.2-2.2 \times 10^{8} \\
\mathrm{CFU} / \mathrm{mL}\end{array}$ & $2 \mathrm{CFU} / \mathrm{mL}$ & $0.28 \mathrm{~V}$ & - \\
\hline $\begin{array}{l}\text { Sandwich configuration of antibodies and } \\
\text { carboxylic acid altered MBs. }{ }^{127}\end{array}$ & $\begin{array}{l}\text { Food } \\
\text { allergen Ara } \\
\text { h } 1\end{array}$ & $\begin{array}{l}20.8 \text { and } 1000.0 \\
\mathrm{ng} \mathrm{mL}^{-1}\end{array}$ & $6.3 \mathrm{ng} \mathrm{mL}^{-1}$ & $-0.20 \mathrm{~V}$ & - \\
\hline
\end{tabular}

'-'Refers as not mentioned

\section{CONCLUSION}

Amperometric biosensors are seen to have promising industrial applications especially because of the incompetence of the conventional methods. Different types of electrodes, matrix, and immobilization techniques have been applied and experimented with samples to improve the biosensor characteristics, enhance the working efficiency, and prepare for mass usage. The demand for biosensors in the food, dairy, fermentation industries is immense. The use of biosensors in the field of medicine has made the diagnosis of diseases very rapid yet reliable and biosensors employed in the pharmaceutical industries have made a quality analysis of the components very simple and rapid. Biosensors hence have successfully replaced the prevalent time-consuming methodologies of these industries and have shown great potential in all other industrial domains as well. The future of these industries awaits biosensors because of low cost, low LOD, high sensitivity, and other improved analytical properties than classical methods. Many MNCs have invested in biosensors for their application in the industries. The industrial application of these biosensors brings economic and public health welfare, hence enhancing the quality of life. Although the prototype of these biosensors has been 
created, tested, and modified for mass applications, industrial employment of these biosensors is yet to be done. Continuous research is however very essential to combat the limitations of these biosensors so that the society can reap the benefits associated and thereby, the ultimate aim to deliver high-quality products to the consumers can be achieved.

\section{REFERENCES}

1. Turner Anthony, Wilson George, Kaube Isao, Biosensors: Fundamentals and Applications. Oxford, UK: Oxford University Press, 1987.

2. Sassolas A, Blum $\amalg$, Leca-Bouvier BD, Immobilization strategies to develop enzymatic biosensors. Biotechnol Adv., 30, 2012, 489-511. DOI:10.1016/j.biotechadv.2011.09.003

3. Nambiar S, Yeow JT, Conductive polymer-based sensors for biomedical applications,Biosens Bioelectron,26, 2011,1825-1832. doi:10.1016/j.bios.2010.09.046.

4. Daniel R. Thévenot, Klara Toth, Richard A. Durst, George S. Wilson, Electrochemical biosensors: recommended definitions and classification 1 International Union of Pure and Applied Chemistry: Physical Chemistry Division, Commission 1.7 (Biophysical Chemistry); Analytical Chemistry Division, Commission V.5 (Electroanalytical Chemistry).1, Biosensors and Bioelectronics, Volume 16, Issues 1-2,2001,121-131.

\section{https://doi.org/10.1016/S0956-5663(01)00115-4.}

5. Damborský P, Švitel J, Katrlík J. Optical biosensors. Essays Biochem.,60(1),2016,91-100.

https://dx.doi.org/10.1042\%2FEBC20150010.

6. Petr Skládal, Piezoelectric biosensors, TrAC Trends in Analytical Chemistry, Volume 79, 2016, Pages 127-133.

https://doi.org/10.1016/j.trac.2015.12.009.

7. Klaus Mosbach,Thermal biosensors,Biosensors and Bioelectronics, Volume 6, Issue 3,1991,Pages 179-182.

\section{https://doi.org/10.1016/0956-5663(91)80002-F.}

8. Thévenot DR, Toth K, Durst RA, Wilson G, Electrochemical biosensors: recommended definitions and classification. Biosens Bioelectron, Elsevier, 16, 2001, pp.121 - 131. ff10.1081/AL100103209ff.

9. Yunus S., Jonas A.M, Lakard B, Potentiometric Biosensors. In: Roberts G.C.K. (eds) Encyclopedia of Biophysics.Springer, Berlin, Heidelberg, 2013,1941-1946.

\section{https://doi.org/10.1007/978-3-642-16712-6 714.}

10. Sadeghi S.J., Amperometric Biosensors. In: Roberts G.C.K. (eds) Encyclopedia of Biophysics. Springer, Berlin, Heidelberg, 2013.6167.

\section{https://doi.org/10.1007/978-3-642-16712-6 713.}

11. S. Dzyadevych, N. Jaffrezic-Renault, R. Paul Schaudies, 6 Conductometric biosensors, Biological Identification, Woodhead Publishing,2014,153-193.

\section{https://doi.org/10.1533/9780857099167.2.153}

12. Sadana A., Binding and Dissociation Kinetics for Different Biosensor Applications Using Fractals, 2006, 384.

https://doi.org/10.1016/B978-0-444-52784-4.X5000-X

13. Paul D'Orazio,Biosensors in clinical chemistry,Clinica Chimica Acta,Volume 334, Issues 1-2,2003,Pages 41-69.

https://doi.org/10.1016/50009-8981(03)00241-9.
14. Sanjay Kisan Metkar, Koyeli Girigoswami, Diagnostic biosensors in medicine - A review, Biocatalysis, and Agricultural Biotechnology, Volume 17,2019, Pages 271-283.

https://doi.org/10.1016/j.bcab.2018.11.029.

15. V.Venugopal, Biosensors in fish production and quality control, Biosensors and Bioelectronics, Volume 17, Issue 3,2002, Pages 147157

\section{https://doi.org/10.1016/S0956-5663(01)00180-4}

16. K. Baryeh, S. Takalkar, M. Lund, G. Liu,1, Roger J. Narayan Introduction to medical biosensors for point of care applications, Medical Biosensors for Point of Care (POC) Applications, Woodhead Publishing,2017, Pages 3-25

https://doi.org/10.1016/B978-0-08-100072-4.00001-0

17. Kišija, Emina \& Osmanović, Dina \& Nuhić, Jasna \& Cifrić, Selma, Review of Biosensors in Industrial Process Control, 2020.CMBEBIH, 2019 , pp.687-694.

18. Schügerl K. Bioreactor Instrumentation and Biosensors. In: Moreira A.R., Wallace K.K. (eds) Computer and Information Science Applications in Bioprocess Engineering. NATO ASI Series (Series E: Applied Sciences), vol 305. Springer, Dordrecht, 1996,

https://doi.org/10.1007/978-94-009-0177-3_7

19. Sharma, Ambika, Role of Biosensors in the Field of Veterinary Practice. Indian Journal of Agriculture Business, 2016.

20. Shaheen, Aysha \& Arshad, Rabia \& Taj, Ayesha \& Latif, Usman \& Bajwa, Sadia, Biosensor Applications for Viral and Bacterial Disease Diagnosis, 2020,117-148.

\section{DOI: $10.1002 / 9783527345137 . c h 6$}

21. Sergio Leonardo Florez, Mabel Juliana Noguera, Olga P. Fuentes, Paola Ruiz Puentes, Juan C. Cruz 2and Johann F. Osma, EnzymeBased Electrochemical Biosensors for Microfluidic Platforms to Detect Pharmaceutical Residues in Wastewater, Colombia, 9(1), 2019, 41.

doi:10.3390/bios9010041

22. Ejeian, Fatemeh \& Etedali, Parisa \& Mansouri-Tehrani, HajarAlsadat \& Soozanipour, Asiyeh \& Low, Ze-Xian Nicholas \& Asadnia, Mohsen \& Taheri-Kafrani, Asghar \& Razmjou, Amir, Biosensors for wastewater monitoring: A review. Biosensors and Bioelectronics, 2018, 66-79.

DOI:10.1016/j.bios.2018.07.019.

23. Zammit CM, Quaranta D, Gibson S, Zaitouna AJ, Ta C, et al. A WholeCell Biosensor for the Detection of Gold, PLOS ONE 8(8),2013.

https://dx.doi.org/10.1371\%2Fjournal.pone.0069292

24. 24. Paddle BM, Biosensors for chemical and biological agents of defense interest. Biosens Bioelectron, 1996, 1079-1113.

\section{DOI:10.1016/0956-5663(96)82333-5}

25. Liu G, Lin Y, Electrochemical sensor for organophosphate pesticides and nerve agents using zirconia nanoparticles as selective sorbents. Anal Chem,77(18),2015,5894-5901.

doi:10.1021/ac050791t

26. Koyun, Ahmet \& Ahlatcioglu Özerol, Esma \& İpek, Yeliz, Biosensors, and Their Principles, 2012.

27. Sadeghi S.J., Amperometric Biosensors. In: Roberts G.C.K. (eds) Encyclopedia of Biophysics. Springer, Berlin, Heidelberg,2013.

\section{https://doi.org/10.1007/978-3-642-16712-6 713}

28. Kriz D, Berggren C, Palmqvist E., Sire-technology. Instrumentation Science \& Technology, 1998,69-79. 
29. Fatam Arslan, Selvan Ustabas, and Halit Arslan, An Amperometric Biosensor for Glucose Determination Prepared from Glucose Oxidase Immobilized in Polyaniline-Polyvinyl Sulfonate Film, 11(8),2011,8152-63.

\section{doi:10.3390/s110808152}

30. Artigues, M., Abellà, J., \& Colominas, S. Analytical Parameters of an Amperometric Glucose Biosensor for Fast Analysis in Food Samples. Sensors, 17(11), 2017.

\section{doi:10.3390/s17112620}

31. Andjelkovic, U.; Gavrovic-Jankulovic, M.; Martinovic, T.; Josic, D. Omics methods as a tool for investigation of food allergies. TRAC Trends in Analytical Chemistry, 2017,107-115.

https://doi.org/10.1016/j.trac.2017.07.011

32. Ye, W.; Guo, J.; Bao, X.; Chen, T.; Weng, W.; Chen, S.; Yang, M. Rapid and sensitive detection of bacteria response to antibiotics using nanoporous membrane and graphene quantum dot (gqds)-based electrochemical biosensors. Materials, 10(6),2017 May 31, 603.

doi:10.3390/ma10060603

33. Singh, R.; Mukherjee, M.D.; Sumana, G.; Gupta, R.K.; Sood, S.; Malhotra, B.D.Biosensors for pathogen detection: A smart approach towards clinical diagnosis. Sensors and Actuators B: Chemical, 2014.

\section{https://doi.org/10.1016/i.snb.2014.03.0050}

34. Malhotra, B.D.; Srivastava, S.; Ali, M.A.; Singh, C. Nanomaterialbased biosensors for food toxin detection. Applied Biochemistry and Biotechnology, 174(3),2014.880-896

\section{DOI:10.1007/s12010-014-0993-0}

35. Lavecchia, T.; Tibuzzi, A.; Giardi, M.T. Biosensors for functional food safety and analysis. Giardi, M.T.; Rea, G.; Berra, B., Eds. Springer US: Boston, MA, 2010,267-281

$$
\text { DOI:10.1007/978-1-4419-7347-4_20 }
$$

36. Minika Chetry, Nilakshi Mazumder, Diksha Gupta, and Shilpa Sivashankar, Biotechnological Applications of Electrochemical Biosensors: A Review, Volume 11, Issue 3, 2020 (May - June).

37. Zhang, D.; Liu, Q. Biosensors and bioelectronics on smartphones for portable biochemical detection. Biosensors and Bioelectronics, 2016, 273-284.

\section{https://doi.org/10.1016/j.bios.2015.08.037}

38. B. J. SCHAERTEL, RUTH FIRSTENBERG-EDEN, Biosensors in the Food Industry: Present and Future. J Food Prot,1, October 1988, 811-820. DOI:10.4315/0362-028X-51.10.811

39. H.-W. Wen, W. Borejsza-Wysocki, T.R. DeCory, R.A. Durst, Peanut allergy peanut allergens, and methods for the detection of peanut contamination in food products, Compr. Rev. Food Sci. Food Saf.,6(2), 2007, 47-58.

\section{https://doi.org/10.1111/j.1541-4337.2007.00017.x}

40. Susanna Buratti, Simona Benedetti, Chapter 28 - Alcoholic Fermentation Using Electronic Nose and Electronic Tongue, Editor(s): María Luz Rodríguez Méndez,Electronic Noses and Tongues in Food Science,Academic Press, 2016,332.

\section{https://doi.org/10.1016/C2013-0-14449-2}

41. El-Mansi EMT, Bryce CFA: Fermentation Microbiology and Biotechnology. CRC Press, 2006.

42. Frédéric Leroy, Luc De Vuyst, Lactic acid bacteria as functional starter cultures for the food fermentation industry, Trends in Food Science \& Technology, Volume 15, Issue 2,2004,67-78.

https://doi.org/10.1016/j.tifs.2003.09.004
43. M. Boujtita, M. Chapleau, N. El Murr, Biosensors for analysis of ethanol in food: effect of the pasting liquid, Analytica Chimica Acta, Volume 319, Issues 1-2,1996,91-96.

\section{https://doi.org/10.1016/0003-2670(95)00482-3}

44. Santos, A.S.; Freire, R.S.; Kubota, L.T. Highly Stable Amperometric Biosensor for Ethanol Based on Meldola's Blue Adsorbed on Silica Gel Modified with Niobium Oxide. J Electroanal Chem, $547,2003,135-142$.

\section{https://doi.org/10.1016/S0022-0728(03)00186-4}

45. Vinita Hooda, Vikas Kumar, Anjum Gahlaut \& Vikas Hooda: A novel amperometric bienzymatic biosensor based on alcohol oxidase coupled PVC reaction cell and nanomaterials modified working electrode for rapid quantification of alcohol, Preparative Biochemistry and Biotechnology, 2018;48(10):877-886.

\section{DOI: $10.1080 / 10826068.2018 .1514515$}

46. Gonchar MV, Maidan MM, Moroz OM, Woodward JR, Sibirny AA. Microbial O2- and H2O2-electrode sensors for alcohol assays based on the use of permeabilized mutant yeast cells as the sensitive bioelements. Biosens Bioelectron, 1998;13(9):945-952.

\section{doi:10.1016/s0956-5663(98)00034-7}

47. Reshetnikov, A.N., Lobanov, A.V., Morozova, N.O., Gordon, S.H., Greene, R.V., and Leathers, T.D. Biosens. Bioelectron,1998.

48. L, Rotariu \& Bala, Camelia \& V, Magearu,New potentiometric microbial biosensor for ethanol determination in alcoholic beverages,Analytica Chimica Acta,513,2004,119-123.

\section{https://doi.org/10.1016/j.aca.2003.12.048}

49. Pundir CS, Narwal V. A Bird's Eye View of Lactate Biosensors. J Intensive \& Crit Care,2017.

50. Wikipedia contributors. (2020, January 17). Horseradish peroxidase. In Wikipedia, The Free Encyclopedia. Retrieved 07:50, August 5, 2020 from https://en.wikipedia.org/w/index.php?title=Horseradish_peroxida se\&oldid=936175669

51. Pérez S, Fàbregas E. Amperometric bienzymatic biosensor for Llactate analysis in wine and beer samples. Analyst, 2012;137(16):3854-3861.

\section{DOI: $10.1039 / c 2 a n 35227 c$}

52. Shkotova, Lyudmyla \& Goriushkina, Tatiana \& Tran-Minh, Canh \& Chovelon, Jean-Marc \& Soldatkin, Alexei \& Dzyadevych, Sergei.: Amperometric biosensor for lactate analysis in wine and must during fermentation. Materials Science and Engineering,2008,943948.

\section{https://doi.org/10.1016/j.msec.2007.10.038}

53. Huizhi Kang, Lin Wang, Meghan O'Donoghue, Y. Charles Cao, Weihong Tan, Chapter 15 - NANOPARTICLES FOR BIOSENSORS, Editor(s): Frances S. Ligler, Chris Rowe Taitt, Optical Biosensors (Second Edition), Elsevier, 2008.

54. L. Shkotova, A. Bohush, I. Voloshina, O. Smutok, S. Dzyadevych, Amperometric biosensor modified with platinum and palladium nanoparticles for detection of lactate concentrations in wine, SN Applied Sciences,2019

\section{DOI: $10.1007 / \mathrm{s} 42452-019-0315-9$}

55. Goriushkina, Tatiana \& Soldatkin, Alexei \& Dzyadevych, Sergei. Application of Amperometric Biosensors for Analysis of Ethanol, Glucose, and Lactate in Wine. Journal of agricultural and food chemistry.57(15), 2009,6528-6535.

\section{https://doi.org/10.1021/jf9009087}

56. S. Piermarini, G. Volpe, M. Esti, M. Simonetti, G. Palleschi, Real-time monitoring of alcoholic fermentation with low-cost amperometric biosensors, Food Chemistry, Volume 127, Issue 2, 2011,749-54. 


\section{https://doi.org/10.1016/i.foodchem.2011.01.008}

57. Luca, S \& Florescu, Monica \& Ghica, Mariana \& Lupu, A \& Palleschi, Giuseppe \& Brett, Christopher \& Compagnone, Dario.: Carbon film electrodes for oxidase-based enzyme sensors in food analysis. Talanta,127(12),2006,749-54.

\section{https://doi.org/10.1016/j.talanta.2005.06.017}

58. Conner, J. G., Eckersall, P. D., Doherty, M. \& Douglas, T. A.: Acute phase response and mastitis in the cow. Research in Veterinary Science,41(1),1986,126-128.

\section{DOI: $10.1016 / \mathrm{s} 0034-5288(18) 30585-x$}

59. J.G. Zadow, Lactose: Properties and Uses, Journal of Dairy Science, Volume 67, Issue 11,1984,2654-2679.

\section{https://doi.org/10.3168/jds.S0022-0302(84)81625-2}

60. An Integrated Amperometric Biosensor for the Determination of Lactose in Milk and Dairy Products.F. Conzuelo, M. Gamella, S. Campuzano, M.A. Ruiz, A. J. Reviejo, and J. M. Pingarrón*Journal of Agricultural and Food Chemistry,58(12),2019,7141-7148.

\section{https://doi.org/10.1021/jf101173e}

61. P.V. Climent, M.L.M. Serralheiro, M.J.F. Rebelo. Development of a new amperometric biosensor based on polyphenol oxidase and polyethersulphone membrane. Pure Appl. Chem. 73-12,2001,1749016.

\section{DOI: $10.1351 /$ pac200173121993}

62. Lourenço, R.J.M. \& Serralheiro, Maria Luisa \& Rebelo, Maria.:Development of a New Amperometric Biosensor for Lactose Determination. Portugaliae Electrochimica Acta,21(12),2003,171177.

\section{DOI: $10.4152 /$ pea. 200302171}

63. Chauhan, Nidhi \& Singh, Anamika \& Narang, Jagriti \& Dahiya, Swati \& Pundir, C. Development of amperometric lysine biosensors based on $\mathrm{Au}$ nanoparticles/multiwalled carbon nanotubes/polymers modified Au electrodes. The Analyst.,137(21),2012,5113-5122.

\section{DOI: $10.1039 / c 2 a n 35629 e$}

64. Anastassiadis S. L-lysine fermentation. Recent Pat Biotechnol.,1(1), 2007,11-24.

65. N. Kiba, T. Miwa, M. Tachibana, K. Tani, and H. Koizumi, Chemiluminometric Sensor for Simultaneous Determination of IGlutamate and I-Lysine with Immobilized Oxidases in a Flow Injection System, Analytical Chemistry, 74, 6, 2002, 1269-1274

\section{https://doi.org/10.1021/ac011013d}

66. Bóka, B., Korózs, M., Nánási, M. and Adányi, N. Novel Amperometric Tri-Enzyme Biosensor for Lysine Determination in Pharmaceutical Products and Food Samples. Electroanalysis,27,2015, 817 - 824

\section{DOI: 10.1002/elan.201400600}

67. Andreescu S, Luck LA. Studies of the binding and signaling of surface-immobilized periplasmic glucose receptors on gold nanoparticles: a glucose biosensor application. Anal Biochem.375(2),2007,282-290.

\section{https://doi.org/10.1016/j.ab.2007.12.035}

68. Swallow DM. Genetics of lactase persistence and lactose intolerance. Annu Rev Genet,37,2003,197-219.

\section{doi:10.1146/annurev.genet.37.110801.143820}

69. Pilloton, R.; Mascini, M.; Casella, I.G.; Festa, M.R.; Bottari, E. Lactose determination in raw milk with a two-enzyme based electrochemical sensor. Anal. Lett. 1987,1803-1814.

DOI: $10.1080 / 00032718708082597$
70. Amman, M.; Fransaer, J. Two-enzyme lactose biosensor based on $\beta$ galactosidase and glucose oxidase deposited by AC-electrophoresis: Characteristics and performance for lactose determination in milk. Sens. Actuators B Chem.,2010,525-533.

\section{https://doi.org/10.1016/j.snb.2010.05.027}

71. De Oliveira, R.F.; De Barros, A.; Ferreira, M. Nanostructured films: Langmuir-Blodgett (LB) and layer-by-layer (LbL) techniques. In Nanostructured; Da Roz, A.L., Ferreira, M., Leite, F.L., Oliveira, O.N., Jr.Eds.; Elsevier Inc.: Amsterdam, The Netherlands, 2016.

\section{https://doi.org/10.1016/B978-0-323-49782-4.00004-8}

72. Salvo-Comino, Coral \& García-Hernández, Celia \& García-Cabezón, Cristina \& Rodríguez-Méndez, María.. Discrimination of Milks with a Multisensor System Based on Layer-by-Layer Films. Sensorps,2018,18(8),2716.

DOI: $10.3390 / s 18082716$

73. Santos PM, Pereira-Filho ER, Rodriguez-Saona LE. Rapid detection and quantification of milk adulteration using infrared microspectroscopy and chemometrics analysis. Food Chemistry.138(1),2013,19-24.

https://doi.org/10.1016/j.foodchem.2012.10.024

74. Borková M., Snášelová J.: Possibilities of different animal milk detection in milk and dairy products - a review. Czech J. Food Sci.,23(2),2005,41-50.

\section{DOI: 10.17221/3371-CJFS}

75. Abdelfatah, E. N.; El-Araby, I. E.; Mohamed, Identification of Species Adulteration in Raw Milk and Butter Using Polymerase Chain Reaction -Restriction Fragment Length Polymorphism., A. A. R. Global Veterinaria, 15(3),15, 2015.332-338

\section{DOI: 10.5829/idosi.gv.2015.15.03.10128}

76. Víctor Ruiz-Valdepeñas Montiel,Eloy Povedano, Sara Benede',, Luis Mata,§ Patricia Galan-Malo,' § María Gamella, A. Julio Reviejo, Susana Campuzano, ${ }^{*}$, and JoséM. Pingarroń ${ }^{*}$,Disposable Amperometric Immunosensor for the Detection of Adulteration in Milk through Single or Multiplexed Determination of Bovine, Ovine, or Caprine Immunoglobulins G Anal. Chem. 2019;91(17):1126611274.

\section{https://doi.org/10.1021/acs.analchem.9b02336}

77. M. J. R. Leema, S.M. V.Fernandes, and A. O. S. Rangel, J. Agric Food Chem, March $13^{\text {th }} 2013$, DOI: $10.5772 / 56353$

78. Hof G, Vervoorn MD, Lenaers PJ, Tamminga S. Milk urea nitrogen as a tool to monitor the protein nutrition of dairy cows. J Dairy Sci. ,1997,3333-3340.

\section{doi:10.3168/jds.S0022-0302(97)76309-4}

79. Florina Brânzoi and Viorel Brânzoi.Amperometric Urea Biosensor Based Metallic Substrate Modified with a Nanocomposite Film, State of the Art in Biosensors - Environmental and Medical Applications, Toonika Rinken, IntechOpen, March 13th, 2013.

\section{DOI: $10.5772 / 52440$}

80. Allmann M, Höfelein C, Köppel E, et al. Polymerase chain reaction (PCR) for detection of pathogenic microorganisms in bacteriological monitoring of dairy products. Res Microbiol. 1995,85-97.

DOI:10.1016/0923-2508(96)80273-7

81. Liu, Dongyou. Identification, subtyping, and virulence determination of Listeria monocytogenes, an important foodborne pathogen. Journal of medical microbiology.2006, 645-659.

doi:10.1099/jmm.0.46495-0

82. Lu, Ying \& Liu, Yongling \& Zhao, Yong \& Li, Wenjiao \& Qiu, Longbing \& Li, Li. : A Novel and Disposable Enzyme-Labeled Amperometric 
Immunosensor Based on MWCNT Fibers for Listeria monocytogenes Detection. Journal of Nanomaterials. 2016,1-8.

\section{DOI: $10.1155 / 2016 / 3895920$}

83. Muhammad-Tahir Z, Alocilja EC. A conductometric biosensor for biosecurity.Biosens Bioelectron. 2003,813-819.

\section{doi:10.1016/s0956-5663(03)00020-4.}

84. Janet, Itelima.: African Journal of Microbiology Research Antimicrobial activity of selected plant species and antibiotic drugs against Escherichia coli O157: H7. African journal of microbiology research,2017,792-803.

\section{DOI: 10.5897/AJMR2017.8440}

85. G. Sberveglieri, G. Faglia, S. Groppelli, P. Nelli, Methods for the preparation of $\mathrm{NO}, \mathrm{NO} 2$, and $\mathrm{H} 2$ sensors based on tin oxide thin films, grown by means of the r.f. magnetron sputtering technique, Sensors and Actuators B: Chemical, Volume 8, Issue 1,1992,79-88.

\section{https://doi.org/10.1016/0925-4005(92)85012-L}

86. Park, J. Y., Park, K., Ok, G., Chang, H. J., Park, T. J., Choi, S. W., \& Lim, M. C.: Detection of Escherichia coli 0157: H7 Using Automated Immunomagnetic Separation and Enzyme-Based Colorimetric Assay. Sensors Basel, Switzerland,2020,1395.

\section{https://doi.org/10.3390/s20051395}

87. Anderson, M., Hinds, P., Hurditt, S., Miller, P., McGrowder, D., \& Alexander-Lindo, R.: The microbial content of unexpired pasteurized milk from selected supermarkets in a developing country. Asian Pacific journal of tropical biomedicine,2011,205-11.

\section{DOI: $10.1016 / S 2221-1691(11) 60028-2$}

88. Nidhi Dhull, Gurpreet Kaur, Prateek Jain, Priyanka Mishra, Divya Singh, Lilly Ganju, Vinay Gupta, Monika Tomar, Label-free amperometric biosensor for Escherichia coli 0157: H7 detection, Applied Surface Science, Volume 495,2019,143548.

DOI: 10.1016/j.apsusc.2019.143548

89. L. Muresan, R. Ronda Valera, I. Frobort, I. Popescu, E. Csoregi, M. Nistor, Amine oxidase amperometric biosensor coupled to liquid chromatography for biogenic amines determination, Microchimica Acta 163 2008,219-225.

\section{DOI: $10.1007 / \mathrm{s} 00604-008-0033-2$}

90. M.A. Alonso-Lomillo, O. Dominguez-Renedo, P. Matos, M.J. ArcosMartinez, Disposable biosensors for determination of biogenic amines, Analytica Chimica Acta 665 2010,26-31.

DOI: 10.1016/j.aca.2010.03.012

91. A. Yassoralipour, J. Bakar, R.A. Rahman, F.A. Bakar, Biogenic amines formation in barramundi(Lates calcarifer) fillets at $8{ }^{\circ} \mathrm{C}$ kept in modified atmosphere pack-aging with varied $\mathrm{CO} 2$ concentration, LWT - Food Science and Technology 48 2012,142-146.

\section{DOI: 10.1016/j.Iwt.2012.01.033.}

92. Tabanelli, Giulia \& Coloretti, Fabio \& Chiavari, Cristina \& Grazia, Luigi \& Lanciotti, Rosalba \& Gardini, Fausto. Effects of starter cultures and fermentation climate on the properties of two types of typical Italian dry fermented sausages produced under industrial conditions. Food Control. Food Control 26,2012,416-426.

\section{https://doi.org/10.1016/j.foodcont.2012.01.049}

93. Guidi LR, Gloria MB. Bioactive amines in soy sauce: validation of the method, occurrence, and potential health effects [published correction appears in Food Chem. 2015 Sep 1;182:333]. Food Chem. 2012,323-328.

\section{DOI: 10.1016/j.foodchem.2012.01.033}

94. Ali R. Shalaby, Significance of biogenic amines to food safety and human health, Food Research International, Volume 29, Issue 7,1996,675-690.
https://doi.org/10.1016/S0963-9969(96)00066-X

95. C. Proestos, P. Loukatos, M. Komaitis, Determination of biogenic amines in wines by HPLC with precolumn dansylation and fluorimetric detection, Food Chemistry 106 2008,1218-1224.

\section{https://doi.org/10.1016/j.foodchem.2007.06.048}

96. Irina Mirela Apetrei, Constantin Apetrei, Amperometric biosensor based on polypyrrole and tyrosinase for the detection of tyramine in food samples, Sensors and Actuators B: Chemical, Volume $178,2013,40-46$.

DOI: 10.1016/j.snb.2012.12.064

97. Sinell $\mathrm{HJ}$, Control of food-borne infections and intoxications. Int J Food Microbiol. 1995,209-217.

\section{DOI:10.1016/0168-1605(94)00142-s}

98. Henson S. Estimating the incidence of food-borne Salmonella and the effectiveness of alternative control measures using the Delphi method. Int J Food Microbiol. 1997,195-204.

\section{doi:10.1016/s0168-1605(96)01235-4}

99. Newell DG, Koopmans M, Verhoef L, et al. Food-borne diseases - the challenges of 20 years ago still persist while new ones continue to emerge [published correction appears in Int J Food Microbiol. 2011 Feb 28;145(2-3):493]. Int J Food Microbiol. 2010,139.

DOI: 10.1016/j.jifoodmicro.2010.01.021

100. Liu, Yongcheng \& Che, Yihua \& Li, Yanbin.: Rapid detection of Salmonella Typhimurium using immunomagnetic separation and immune-optical sensing method. Sensors and Actuators B: Chemical.2001,214-218.

\section{DOI: $10.1016 /$ S0925-4005(00)00663-8}

101. Liu G, Chai C, Yao B: Rapid Evaluation of Salmonella pullorum Contamination in Chicken Based on a Portable Amperometric Sensor.2013.

\section{DOI: $10.4172 / 2155-6210.1000137$}

102. Benedé S, López-Expósito I, Molina E, López-Fandiño R. Egg proteins as allergens and the effects of the food matrix and processing. Food Funct. 2015,694-713.

\section{doi:10.1039/c4fo01104j}

103. Yang-Te Lin, Chih-Te Wu, Jing-Long Huang, Ju-Hui Cheng, Kuo-Wei Yeh, Correlation of ovalbumin of egg white components with allergic diseases in children, Journal of Microbiology, Immunology and Infection, Volume 49, Issue 1,2016,112-118.

\section{DOI: 10.1016/j.jmii.2014.01.002}

104. Matsuda T, Watanabe K, Nakamura R. Immunochemical studies on thermal denaturation of ovomucoid. Biochim Biophys Acta. 1982,121-128.

\section{DOI:10.1016/0167-4838(82)90404-6}

105. T. Matsuda, K. Watanabe, R. Nakamura, Immunochemical, and physical properties of peptic-digested ovomucoid, J. Agric. Food Chem. 31 1983,942-946.

\section{DOI:10.1021/jf00119a005}

106. K. Honma, M. Aoyagi, K. Saito, T. Nishimuta, K. Sugimoto, H. Tsunoo, H. Niimi, Y. Kohno, Antigenic determinants on ovalbumin and ovomucoid: comparison of the specificity of IgG and IgE antibodies. Arerugi 40 1991,1167-1175.

107. Cooke SK, Sampson HA. Allergenic properties of ovomucoid in man J Immunol. 1997,2026-2032.

108. Leduc V, Demeulemester C, Polack B, Guizard C, Le Guern L, Peltre G. Immunochemical detection of egg-white antigens and allergens in meat products. Allergy.1999,464-472. 
doi:10.1034/j.1398-9995.1999.00928.x

109. Kato $Y$, Oozawa E, Matsuda T. Decrease in antigenic and allergenic potentials of ovomucoid by heating in the presence of wheat flour: dependence on wheat variety and intermolecular disulfide bridges. J Agric Food Chem. 2001,3661-3665.

\section{doi:10.1021/jf0102766}

110. S. Benedé, V. Ruiz-Valdepeñas Montiel, E. Povedano, M. Villalba, L. Mata, P. Galán-Malo, R.M. Torrente-Rodríguez, E. Vargas, A.J. Reviejo, S. Campuzano, J.M. Pingarrón,Fast amperometric immunoplatform for ovomucoid traces determination in fresh and baked foods,Sensors and Actuators B: Chemical, Volume 265,2018,421-428.

DOI: 10.1016/j.snb.2018.03.075

111. Puiu, Mihaela \& Istrate, Oana \& Rotariu, Lucian \& Bala, Camelia. Kinetic approach of aflatoxin B1-acetylcholinesterase interaction: A tool for developing surface plasmon resonance biosensors. Analytical biochemistry,2011,587-594.

DOI: 10.1016/j.ab.2011.10.035

112. Johnson FA, Craig DQ, Mercer AD. Characterization of the block structure and molecular weight of sodium alginates. J Pharm Pharmacol, 1997,639-643.

doi:10.1111/j.2042-7158.1997.tb06085.x

113. Orive G, Hernández RM, Gascón AR, et al. Cell encapsulation: promise and progress. Nat Med. 2003,104-107.

\section{doi:10.1038/nm0103-104}

114. Sharma, Neeru \& Sawhney, S.K. Stability and properties of mushroom tyrosinase entrapped in alginate, polyacrylamide, and gelatin gels. Enzyme and Microbial Technology,2002,613-619.

\section{DOI: 10.1016/S0141-0229(02)00019-4}

115. Rodica E. Ionescu, Khalil Abu-Rabeah, Serge Cosnier, Robert S. Marks, Improved enzyme retention from an electropolymerized polypyrrole-alginate matrix in the development of biosensors, Electrochemistry Communications, Volume 7, Issue 12,2005,12771282.

\section{DOI: 10.1016/j.elecom.2005.09.009}

116. Cosnier, Serge \& Novoa, Andres \& Mousty, Christine \& Marks, Robert. Biotinylated alginate immobilization matrix in the construction of an amperometric biosensor: Application for the determination of glucose. Analytica Chimica Acta - ANAL CHIM ACTA, 2002,71-79.

\section{DOI: $10.1016 / S 0003-2670(01) 01485-4$}

117. Ding, C.F.; Zhang, M.L.; Zhao, F.; Zhang, S.S. Disposable biosensor and biocatalysis of horseradish peroxidase based on sodium alginate film and room temperature ionic liquid. Anal. Biochem. 2008,32-37.

DOI: 10.1016/j.ab.2008.03.036

118. Chrouda, A.; Zinoubi, K.; Soltane, R.; Alzahrani, N.; Osman, G.; AlGhamdi, Y.O.; Qari, S.; Al Mahri, A.; Algethami, F.K.; Majdoub, H.; Jaffrezic Renault, N. An Acetylcholinesterase Inhibition-Based
Biosensor for Aflatoxin B1 Detection Using Sodium Alginate as an Immobilization Matrix. Toxins 2020,173.

doi: $10.3390 /$ toxins12030173

119. Sakata J, Yonekita T, Kawatsu K. Development of a rapid immunochromatographic assay to detect contamination of raw oysters with enteropathogenic Vibrio parahaemolyticus. Int J Food Microbiol. 2018,16-24.

DOI: 10.1016/j.ijfoodmicro.2017.10.016

120. Raghunath $P$, Acharya $S$, Bhanumathi A, Karunasagar I, Karunasagar I. Detection and molecular characterization of Vibrio parahaemolyticus isolated from seafood harvested along the southwest coast of India 2008,824-830.

DOI: 10.1016/j.fm.2008.04.002

121. Garrido-Maestu A, Chapela MJ, Peñaranda E, Vieites JM, Cabado AG In-house validation of novel multiplex real-time $P C R$ gene combination for the simultaneous detection of the main human pathogenic vibrios. Food Control ,37,2014.

\section{https://doi.org/10.1016/j.foodcont.2013.09.026}

122. Marjan Majdinasab, Akhtar Hayat, Jean Louis Marty, Aptamerbased assays and aptasensors for detection of pathogenic bacteria in food samples, TrAC Trends in Analytical Chemistry, Volume 107,2018,60-77.

DOI: 10.1016/j.trac.2018.07.016

123. Ali MM, Li F, Zhang $Z$, et al. Rolling circle amplification: a versatile tool for chemical biology, materials science, and medicine. Chem Soc Rev. 2014,3324-3341.

DOI: $10.1039 / \mathrm{c} 3 \mathrm{cs} 60439 \mathrm{j}$

124. Teng, Jun \& Ye, Yingwang \& Yao, Li \& Yan, Chao \& Cheng, Kewen \& Xue, Feng \& Pan, Daodong \& Li, Baoguang \& Chen, Wei, Rolling circle amplification-based amperometric aptamer/immuno hybrid biosensor for ultrasensitive detection of Vibrio parahaemolyticus. Microchimica Acta. 184.,2017,3477-3485.

DOI: $10.1007 / \mathrm{s} 00604-017-2383-0$

125. H.-W. Wen, W. Borejsza-Wysocki, T.R. DeCory, R.A. Durst, Peanut allergy peanut allergens, and methods for the detection of peanut contamination in food products, Compr. Rev. Food Sci. Food Saf. 6 2007,

\section{https://doi.org/10.1111/j.1541-4337.2007.00017.x}

126. H. Liu, R. Malhotra, M.W. Peczuh, J.F. Rusling, Electrochemica immunosensors for antibodies to peanut allergen Ara h2 using gold nanoparticle-peptide films, Anal. Chem. 82 2010,5865-71.

DOI: $10.1021 / \mathrm{ac} 101110 \mathrm{q}$

127. V. Ruiz-Valdepeñas Montiel, S. Campuzano, A. Pellicanò, R.M. Torrente-Rodríguez, A.J. Reviejo, M.S. Cosio, J.M. Pingarrón,Sensitive and selective magneto immunosensing platform for determination of the food allergen Ara $h$ 1,Analytica Chimica Acta,2015,52-59.

DOI:10.1016/j.aca.2015.04.041 PMID: 26092337

Source of Support: None declared.

Conflict of Interest: None declared.

For any question relates to this article, please reach us at: editor@globalresearchonline.net New manuscripts for publication can be submitted at: submit@globalresearchonline.net and submit_ijpsrr@rediffmail.com 